\title{
Discovery of a Novel Non-Narcotic Analgesic Derived from the CL-20 Explosive: Synthesis, Pharmacology and Target Identification of Thio- wurtzine, a Potent Inhibitor of the Opioid Receptors and the Voltage- Dependent Calcium Channels
}

\author{
Stephanie Aguero, ${ }^{\mathrm{a}, \#}$ Simon Megy, ${ }^{\mathrm{a}, \#}$ Mailys Fournier, ${ }^{\mathrm{a}}$ Daria A. Kulagina, ${ }^{\mathrm{b} *}$ Sergey V. Sysolyatin, \\ Alexander I. Kalashnikov, b Svetlana G. Krylova, ${ }^{\mathrm{c}}$ Alexander B. Vorozhtsov, ${ }^{\mathrm{d}}$ Vadim V. Zhdanov, ${ }^{\mathrm{c}}$ and \\ Raphael Terreux ${ }^{a *}$ \\ a Équipe ECMO, Laboratoire de Biologie Tissulaire et d’Ingénierie (LBTI), UMR5305, Université Lyon 1, Lyon, France \\ b Institute for Problems of Chemical and Energetic Technologies, Siberian Branch of the Russian Academy of Sciences \\ (IPCET SB RAS), Biysk 659322, Altai Krai, Russia \\ ${ }^{c}$ Goldberg Research Institute of Pharmacology and Regenerative Medicine, Tomsk National Research Medical Center \\ of the Russian Academy of Sciences, Tomsk 634028, Russia \\ d National Research Tomsk State University, Lenin Avenue, 36, Tomsk 634050, Russia
}

KEYWORDS: thiowurtzine, hexaazaisowurtzitane; analgesic activity; chemical synthesis; pharmacophore; pharmacokinetics; calcium channel; opioid receptor; docking; homology modeling; molecular dynamics.

\begin{abstract}
The number of candidate molecules for new non-narcotic analgesics is extremely limited. Here we report the identification of thiowurtzine, a new potent analgesic molecule with promising application in chronic pain treatment. We describe the chemical synthesis of this unique compound derived from the hexaazaisowurtzitane (CL-20) explosive molecule. Then we use animal experiments to assess its analgesic activity in vivo upon chemical, thermal and mechanical exposures, compared to the effect of several reference drugs. Finally, we investigate the potential receptors of thiowurtzine in order to better understand its complex mechanism of action. We use docking, molecular modeling and molecular dynamics simulations to identify and characterize the potential targets of the drug and confirm the results of the animal experiments. Our findings finally indicate that thiowurtzine may have a complex mechanism of action, by targeting the mu, kappa, delta and ORL1 opioid receptors, and the voltage-gated calcium channels as well.
\end{abstract}

\section{INTRODUCTION}

Synthesis of candidate molecules for the design of nonnarcotic analgesics to relieve severe and moderate pain is a trending topic in pharmaceutics. Three types of treatments against pain of different etiologies are primarily used in outpatient and in-patient: (1) opioid and cannabinoid molecules with various analgesic activity, (2) nonsteroidal antiinflammatory drugs (NSAIDs) acting as antalgic molecules, and (3) their various combinations in multimodal approaches for chronic pain, incorporating modalities such as physiotherapy, psychological therapy, patient education and peripheral stimulation. ${ }^{12} 345 \mathrm{An}$ alternative to opiates for severe and moderate pain relief may reside in the use of non-narcotic analgesics acting on the central and peripheral nervous systems. However, the potential candidate molecules for non-narcotic analgesics are extremely limited in number. In this regard, one of the current successful approaches for the discovery of new molecules for biomedical research is the development of high-throughput methods of virtual screening for large databases of chemical compounds. 678

Here we report the development of a new patented analgesic molecule, ${ }^{9}$ hereafter referred as thiowurtzine, and based on the hexaazaisowurtzitane (CL-20) molecule, a substance commonly known as a component of rocket fuel and explosives. Although several explosives such as nitroglycerin or potassium nitrate have been used as drugs in the medical history, 10111213 the case of thiowurtzine is quite different, as it is directly derived from the CL-20 molecule, but lacks all of the 6 nitro groups which confer its explosive properties to CL-20. As the 6 nitro groups are only added during the very last step of the chemical synthesis of CL-20, 14 thiowurtzine can very well be considered more as a modified precursor rather than a revised explosive molecule.

Hexaazaisowurtzitane derivatives are caged polycyclic polynitrogen compounds and possess a framework structure determining their unique properties. ${ }^{15} 16$ Yet, numerous studies focused on the synthesis of new 
hexaazaisowurtzitane derivatives have until recently been primarily focused on their explosive and propelling properties for military purposes, as promising components of solid rocket fuels and composite explosives. 1617

Only in recent years has hexaazaisowurtzitane been investigated as a new pharmacophore for the development of original pharmaceutical substances. In this more biological context, preliminary studies investigating the analgesic activity of hexaazaisowurtzitane derivatives have recently been described: lately, the analgesic activity of thiowurtzine has been characterized in mice. ${ }^{18}$ Its pharmacokinetics in rats ${ }^{19}$ and its concomitant use with cyclophosphamide in mice cancer therapies ${ }^{20}$ have been investigated as well. The aim of the project was to conduct conclusive preclinical studies of this drug based on the hexaazaizowurtzitane molecule for the treatment of pain syndrome caused by different etiologies.

Thiowurtzine is the first chemical compound in the class of hexaazaisowurtzitanes which presents a significant, experimentally validated bioactivity. 2115
In this study, we report the synthesis of 4-(3,4-dibromothiophenecarbonyl)-2,6,8,12-tetraacetyl-2,4,6,8,10,12hexaazatetracyclo $\left[5,5,0,0^{3,11}, 0^{5,9}\right]$ dodecane (thiowurtzine, I), whose properties were predicted using the PASS software package. ${ }^{22}$ Furthermore, we use animal experiments to assess the analgesic activity of thiowurtzine in vivo upon chemical, thermal and mechanical exposures, compared to the effect of several reference molecules. Finally, we investigate the potential receptors of thiowurtzine in order to better understand its mechanism of action. We use docking, molecular modeling and molecular dynamics simulations to identify and characterize the potential targets of the drug and confirm the results of the animal experiments.

\section{RESULTS AND DISCUSSION}

Chemistry. A series of sequential reactions were used for the synthesis of thiowurtzine (I) as a final compound, as illustrated in Scheme 1.

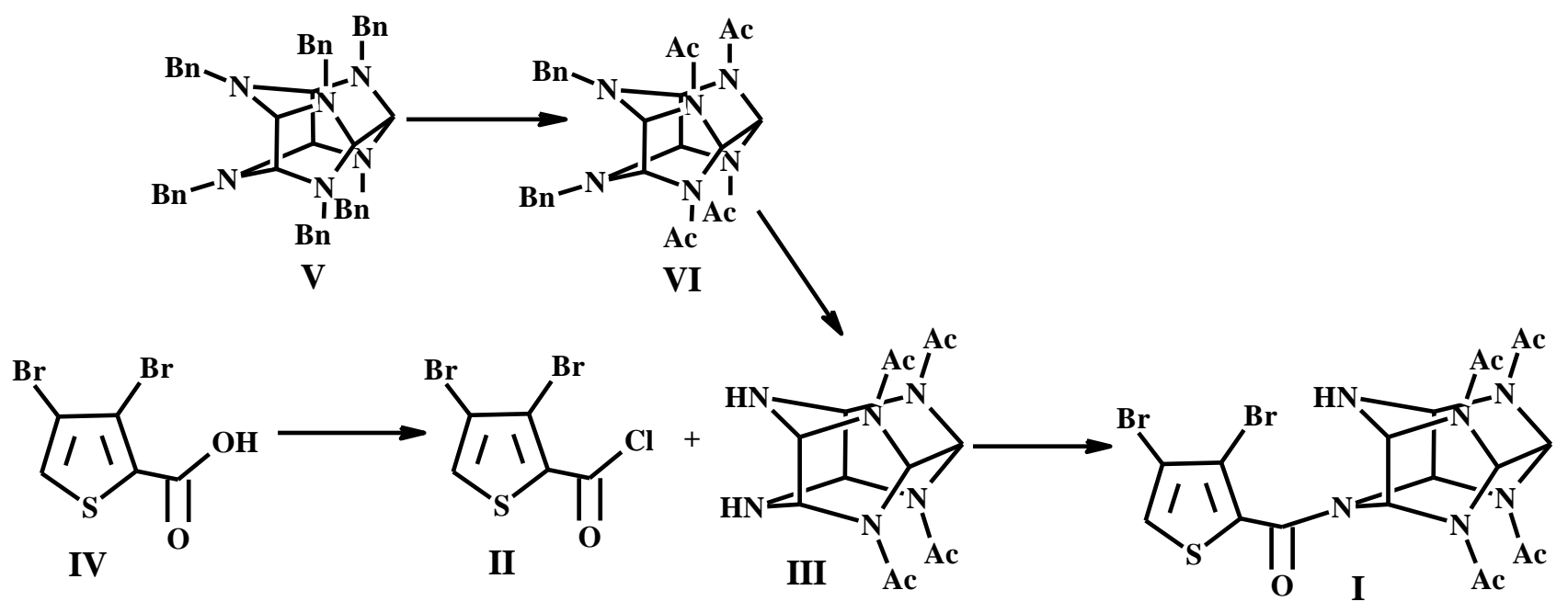

Scheme 1. Synthesis of thiowurtzine (I)

For the synthesis of compound IV, we optimized the procedure involving exhaustive bromination of thiophene, reduction with zinc dust to dibromothiophene, alkylation in the presence of titanium tetrachloride, and final oxidation of the aldehyde to the desired dibromothiophene carboxylic acid IV.

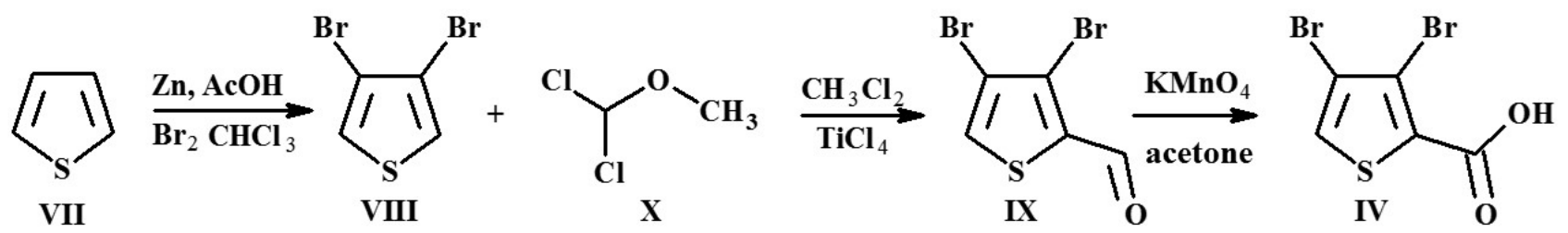

Scheme 2. An optimized procedure for dibromothiophene carboxylic acid (IV)

The yield of IV on a thiophene (VII) basis was 37\%. In case compound VIII was used, the yield of IV was $73 \%$. These reactions are illustrated in Scheme 2. As pictured in Scheme 1, acylating agent II was obtained in a quantitative yield by treating 3,4-dibromothiophene carboxylic acid IV with boiling thionyl chloride for 1 hour.
Synthetic methods for tetraacetyl hexaazaisowurtzitane (III) are commonly known and industrially employed. ${ }^{23} 24$ ${ }^{25}$ A cascade condensation of benzylamine with glyoxal furnished hexabenzyl hexaazaisowurtzitane (V). A twostage hydrogenation of $\mathbf{V}$ over Pd catalyst produced VI (Scheme 1). 
The acylation reaction between the starting III and chloroanhydride II was performed in boiling acetonitrile. The use of other organic solvents diminished the yield of product I. To lower the quantity of impurities, diamine III in acetonitrile was treated with the acylating agent II, with compound I precipitating from the reaction mixture and not undergoing further reactions (Scheme 1).

No excess acylating agent II was required to complete the reaction. When II was used in excess from $0 \%$ to $65 \%$, the yield of I ranged from $79 \%$ to $82 \%$.

The structure of the obtained compound I was verified by a complex approach via physicochemical methods, including ${ }^{1} \mathrm{H}$ and ${ }^{13} \mathrm{C}$ NMR spectra (as illustrated in the Supporting Information).

Biological Evaluation. The predicted analgesic activity of the resulting compound I was confirmed on animals using the reference drugs tramadol, ketorolac, and diclofenac.
Two experimental series with chemical pain stimulation of the peritoneum showed a pronounced antinociceptive effect of thiowurtzine upon a single $(100 \mathrm{mg} / \mathrm{kg})$ and subchronic intragastric administration to mice in doses of 50 and $100 \mathrm{mg} / \mathrm{kg}$ (Table 1). After a single administration (100 mg/kg), thiowurtzine significantly relieved acute visceral pain by $56.4 \%$ and prolonged the pain response time $(\mathrm{p}<0.05)$ in reference to the negative control and appeared to be equivalent to the reference drug tramadol, which exhibits a $62.2 \%$ pain response inhibition (Table 1 , series I). It should be noted that in the second series of experiments, after a 4-day compound administration in doses of 50 and $100 \mathrm{mg} / \mathrm{kg}$, thiowurtzine reduced the number of writhings by $56.9 \%(\mathrm{p}<0.01)$ and $47.1 \%(\mathrm{p}<0.01)$ in comparison with the control, respectively (Table 1 , series II). Thiowurtzine $(50 \mathrm{mg} / \mathrm{kg})$ exceeded in activity the reference drug diclofenac.

Table 1. Anti-nociceptive effect of thiowurtzine in acetic-acid writhing test $(\mathrm{X} \pm \mathrm{m})$

\begin{tabular}{|c|c|c|c|}
\hline Group & $\begin{array}{l}\text { Number of writhings } \\
\text { within } 20 \mathrm{~min}\end{array}$ & $\begin{array}{l}\text { Writhing } \\
\text { latency, sec }\end{array}$ & $\begin{array}{l}\text { Pain response } \\
\text { inhibition, \% }\end{array}$ \\
\hline \multicolumn{4}{|c|}{ Series I: inbred male CBA mice. Single administration of thiowurtzine and Tramadol } \\
\hline $\begin{array}{l}\text { 1. Negative control }- \text { vehicle } \\
(n=9)\end{array}$ & $24.1 \pm 3.4$ & $160.9 \pm 86.4$ & 0 \\
\hline 3. Tramadol, $20 \mathrm{mg} / \mathrm{kg}(\mathrm{n}=9)$ & $\begin{array}{l}9.1 \pm 2.0 \\
* *(1-3)\end{array}$ & $\begin{array}{l}444.8 \pm 42.8 \\
* *(1-3)\end{array}$ & 62.2 \\
\hline $\begin{array}{l}\text { 5.Thiowurtzine, } 100 \mathrm{mg} / \mathrm{kg} \\
(\mathrm{n}=6)\end{array}$ & $\begin{array}{l}10.5 \pm 3.0 \\
*(1-5)\end{array}$ & $\begin{array}{l}382.5 \pm 120.4 \\
*(1-5)\end{array}$ & 56.4 \\
\hline \multicolumn{4}{|c|}{ Series II: outbred female mice, stock CD1. Drug administration for 4 days } \\
\hline $\begin{array}{l}\text { 1. Negative control }- \text { vehicle } \\
(n=10)\end{array}$ & $27.4 \pm 3,1$ & $276 \pm 15$ & - \\
\hline 2. Diclofenac, $10 \mathrm{mg} / \mathrm{kg}(\mathrm{n}=10)$ & $\begin{array}{l}18.2 \pm 1.2 \\
* *(1-2)\end{array}$ & $270 \pm 10$ & 33.6 \\
\hline $\begin{array}{l}\text { 3. Thiowurtzine, } 50 \mathrm{mg} / \mathrm{kg} \\
(\mathrm{n}=10)\end{array}$ & $\begin{array}{l}11.8 \pm 2.9 \\
* *(1-3) \\
*(2-3)\end{array}$ & $270 \pm 10$ & 56.9 \\
\hline $\begin{array}{l}\text { 4.Thiowurtzine, } 100 \mathrm{mg} / \mathrm{kg} \\
(\mathrm{n}=10)\end{array}$ & $\begin{array}{l}14.5 \pm 3.0 \\
* *(1-4)\end{array}$ & $273 \pm 16$ & 47.1 \\
\hline
\end{tabular}

Note. ${ }^{*} \mathrm{p}<0.05,{ }^{* *} \mathrm{p}<0.01$ compared to the negative control and reference group (Mann-Whitney $U$ test).

The most pronounced analgesic effect of thiowurtzine was revealed in the central algesia model, which is controlled by the cortical and subcortical structures of brain. In the hot plate test, subchronic intragastric administration of thiowurtzine in a dose of $100 \mathrm{mg} / \mathrm{kg}$ caused a maximum increase in the pain response latency $77.9 \%$ by 1.8 times $(\mathrm{p}<0.01)$ relative to the control (Table 2 , series I, II). Thiowurtzine $(100 \mathrm{mg} / \mathrm{kg})$ exceeded the activity of the reference drug diclofenac, which pain response inhibition proved to be $11.3 \%$.

Table 2. Analgesic activity of thiowurtzine in hot-plate test in outbred male stock CD rats (X土m)

\begin{tabular}{|l|l|l|}
\hline Group & $\begin{array}{l}\text { Pain response latency, } \\
\text { sec }\end{array}$ & $\begin{array}{l}\text { Pain response inhibi- } \\
\text { tion, } \%\end{array}$ \\
\hline Series I: Drug administration for 4 days
\end{tabular}


bioRxiv preprint doi: https://doi.org/10.1101/2021.03.18.435981; this version posted March 19, 2021. The copyright holder for this preprint (which was not certified by peer review) is the author/funder. All rights reserved. No reuse allowed without permission.

\begin{tabular}{|l|l|l|}
\hline 1. Negative control — vehicle $(\mathrm{n}=8)$ & $9.8 \pm 1.0$ & - \\
\hline 2. Diclofenac, $5 \mathrm{mg} / \mathrm{kg}(\mathrm{n}=9)$ & $10.9 \pm 1.5$ & 11.3 \\
\hline 3. Thiowurtzine, $25 \mathrm{mg} / \mathrm{kg}(\mathrm{n}=9)$ & $10.4 \pm 1.3$ & 6.1 \\
\hline 4. Thiowurtzine, $50 \mathrm{mg} / \mathrm{kg}(\mathrm{n}=8)$ & $12.1 \pm 1.6$ & 23.5 \\
\hline Series II: Drug administration for 4 days & $11.3 \pm 1,0$ & - \\
\hline 1. Negative control - vehicle (n=10) & $20.1 \pm 2.3$ & 77.9 \\
\hline 2. Thiowurtzine, $100 \mathrm{mg} / \mathrm{kg}(\mathrm{n}=10)$ & $* *(1-2)$ & 31.9 \\
\hline 3. Thiowurtzine, $200 \mathrm{mg} / \mathrm{kg}(\mathrm{n}=10)$ & $14.9 \pm 2.1$ & \\
\hline 4. Thiowurtzine, $300 \mathrm{mg} / \mathrm{kg}(\mathrm{n}=10)$ & $13.2 \pm 2,7$ & 16.8 \\
\hline
\end{tabular}

Note. ${ }^{*} \mathrm{p}<0.05,{ }^{* *} \mathrm{p}<0.01$ compared to the negative control and reference group (Mann-Whitney $U$ test).

Thiowurtzine showed a roughly constant increase in the nociceptive threshold throughout the study, which was noted to be significant in the $100 \mathrm{mg} / \mathrm{kg}$ group (Table 3 ). After a single administration $(100 \mathrm{mg} / \mathrm{kg})$, thiowurtzine significantly increased the supporting pressure in the left hind paw pad by 2.1 times $(1 \mathrm{~h}, \mathrm{p}<0.01)$ and 1.6 times $(4$ $\mathrm{h}, \mathrm{p}<0.01$ ), relative to the negative control.

Table 3. Analgesic activity of thiowurtzine in Randall-Selitto test in outbred male stock CD1 mice (X \pm m)

\begin{tabular}{|c|c|c|c|c|}
\hline \multirow[b]{2}{*}{ Group } & \multicolumn{2}{|c|}{$\begin{array}{l}\text { Supporting pressure in left hind paw pad, g/ } \\
\text { Condition }\end{array}$} & \multicolumn{2}{|c|}{$\begin{array}{l}\text { Supporting pressure in right hind paw pad } \\
\text { with formalin edema, g/ Condition }\end{array}$} \\
\hline & $\begin{array}{l}1 \text { hour after } \\
\text { drug administration }\end{array}$ & $\begin{array}{l}4 \text { hours after drug } \\
\text { administration }\end{array}$ & $\begin{array}{l}1 \text { hour after drug ad- } \\
\text { ministration } \\
1-5 \text { min after injection } \\
\text { of formalin }\end{array}$ & $\begin{array}{l}1 \text { hour after drug } \\
\text { administration } \\
40-50 \text { min after in- } \\
\text { jection of formalin }\end{array}$ \\
\hline $\begin{array}{l}\text { 1. Negative control - vehicle } \\
(n=10)\end{array}$ & $294.9 \pm 48.4$ & $373.2 \pm 70.9$ & $141.1 \pm 23,7$ & $305.2 \pm 72.6$ \\
\hline 2. Tramadol, 10 mg/kg (n=9) & $\begin{array}{l}645.2 \pm 40.8 \\
* *(1-2)\end{array}$ & $\begin{array}{l}606.7 \pm 53.9 \\
* *(1-2)\end{array}$ & $\begin{array}{l}318.9 \pm 84.1 \\
*(1-2)\end{array}$ & $\begin{array}{l}518.0 \pm 85.0 \\
*(1-2)\end{array}$ \\
\hline 3. Ketorolac, $6 \mathrm{mg} / \mathrm{kg}(\mathrm{n}=8)$ & $\begin{array}{l}521.2 \pm 107.9 \\
* *(1-3)\end{array}$ & $449.7 \pm 90.4$ & $\begin{array}{l}491.4 \pm 88.2 \\
*(1-3)\end{array}$ & $396.6 \pm 94.1$ \\
\hline $\begin{array}{l}\text { 4.Thiowurtzine, } 100 \mathrm{mg} / \mathrm{kg} \\
(\mathrm{n}=9)\end{array}$ & $\begin{array}{l}631.5 \pm 43.9 \\
* *(1-4)\end{array}$ & $\begin{array}{l}612.9 \pm 43.8 \\
* *(1-4)\end{array}$ & $\begin{array}{l}620.8 \pm 60.0 \\
* *(1-4)\end{array}$ & $\begin{array}{l}611.3 \pm 58.8 \\
* *(1-4)\end{array}$ \\
\hline $\begin{array}{l}\text { 5. Thiowurtzine, } 200 \mathrm{mg} / \mathrm{kg} \\
(\mathrm{n}=9)\end{array}$ & $\begin{array}{l}586.1 \pm 68.6 \\
* *(1-5)\end{array}$ & $455.8 \pm 81.7$ & $\begin{array}{l}419.7 \pm 94.2 \\
*(1-5)\end{array}$ & $366.3 \pm 88.3$ \\
\hline
\end{tabular}

Note. ${ }^{*} \mathrm{p}<0.05,{ }^{* *} \mathrm{p}<0.01$ compared to the negative control and reference group (Mann-Whitney U test).

Interestingly, the Randall-Selitto test performed on the right paw $(100 \mathrm{mg} / \mathrm{kg})$ with formalin edema also revealed a significant increase in the nociceptive threshold. In this case, an increased supporting pressure was evidenced, by 4.4 times $(1 \mathrm{~h}, \mathrm{p}<0.01)$ and 2.0 times $(4 \mathrm{~h}, \mathrm{p}<0.01)$ compared to the negative control.

The assessed effect of thiowurtzine $(100 \mathrm{mg} / \mathrm{kg})$ on thresholds of response to mechanical pressure stimulation appeared to be comparable with tramadol but exceeded the activity of the reference drug ketorolac.

The preclinical study demonstrated that chronic administration of thiowurtzine (abstinence syndrome) did not evoke drug abuse. There was no impact on the respiration and the central nervous systems, indicating that thiowurtzine is not a morphine-like action compound, and does not cause ulcerogenic damage to the gastrointestinal mucosa of the test animals.

Target Identification. Preliminary studies investigating the analgesic activity of thiowurtzine in conjunction with naloxone and naloxone methiodide have been previously published. ${ }^{18}$ Naloxone has been shown to have a higher affinity than naloxone methiodide for opioid $\mathrm{mu}$, kappa, and delta receptors in the brain of the mouse. ${ }^{26}$ Therefore naloxone targets the brain tissue, whereas naloxone methiodide, which has limited access to the brain, targets more specifically the peripheral opioid receptors.

In particular, injection of the non-selective opioid receptor antagonist naloxone was shown to weaken the analgesia caused by a single thiowurtzine administration in a dose of $100 \mathrm{mg} / \mathrm{kg}$, suggesting an action on the opioid mu, 
kappa, and delta receptors in the central opioid system of the mouse. ${ }^{18}$

On the contrary, naloxone methiodide did not abolish analgesia, suggesting that thiowurtzine has no affinity for the peripheral opioid receptors.

These results are consistent with the central opioid system being involved in the mediation of the analgesic effect of thiowurtzine. However, the antinociceptive effect of thiowurtzine was not completely abolished by naloxone, which suggests a complex mechanism of action of the compound under study. In these regards, the opioid analgesia pathway seems to be only one component of the mechanism of action of thiowurtzine, and consequently there may be other receptors targeted.

In order to identify new potential targets for the action of thiowurtzine, we screened the Drugbank ${ }^{27}$ database looking for structurally similar drugs and their wellknown receptors. In particular, we identified several drugs classified as calcium antagonists and acting as calcium channel blockers (namely pranidipine, nicardipine, and especially lacidipine, which exhibited the highest score of $86 \%$ for structural similarity with thiowurtzine). Lacidipine, like other dihydropyridines, targets the voltage dependent calcium channels, and has a selective activity on the $\mathrm{Ca}_{\mathrm{v}}$ 1.2. channel. Dihydropyridines have a high affinity for these receptors ranging from 0.1 to $50 \mathrm{nM}$, and they specifically interact with their $\alpha_{1 \mathrm{c}}$ subunit. ${ }^{28}$ This led us to investigate this class of voltage-gated calcium channels as potential targets for thiowurtzine as well. Indeed, calcium channel blockers have the ability to inhibit voltage-gated calcium channels and thus to reduce the release of neurotransmitters at the presynaptic level, which may lead to pain reduction. As a consequence, voltage-gated calcium channels have been described as targets of choice for potential analgesics in the previous years ${ }^{29} 30313233$, especially when used concomitantly with opioids in attenuation of clinical pain. ${ }^{34} 3536$ In this particular case, calcium channel blockers have been shown to increase morphine analgesia. ${ }^{37} 38$
We used the GOLD ${ }^{39}$ (Genetic Optimization for Ligand Docking) software to perform docking experiments of the thiowurtzine molecule on the mu, kappa, and delta opioid receptors, the opioid like receptor 1 (ORL1), and on the voltage dependent calcium channel $\mathrm{Ca}_{\mathrm{v}} 1.2$ as well

The mu, kappa, delta and ORL1 opioid receptors were constructed using the corresponding UniProtKB human sequences and the I-TASSER software (Iterative Threading ASSEmbly Refinement) from the Zhang Lab. ${ }^{40}$ The models were then checked, charged, and minimized with the MOE software using the AMBER 14:ETH force field.

As no satisfactory structure was available for the mice calcium channel $\mathrm{Ca}_{\mathrm{v}} 1.2$ interacting with a dihydropyridine, we also built a homology model using the UniProtKB sequence Q13936 (isoform 1) of the human voltage-gated calcium channel subunit $\alpha_{1 c} \mathrm{Ca}_{\mathrm{v}} 1.2$ and the PDB structure 6JP5 of the rabbit $\mathrm{Ca}_{\mathrm{v}} 1.1$ / nifedipine complex as a template. The RMSD calculated between the final model and the template was $0.738 \AA$. The RMSD between the binding sites (residues with atoms within a sphere of 4.5 $\AA$ around the nifedipine ligand) of 6JP5 and the homology model was $0.32 \AA$, which indicates that the two binding sites are extremely similar. The Ramachandran diagram of the model was also checked with $93 \%$ of residues in the most favorable regions, $6 \%$ in the allowed regions, and only a few outlier residues. The homology model was further evaluated by docking 9 ligands extracted from the BindingDB (http://bindingdb.org). The docking scores were in very good agreement with the experimentally measured inhibitor constants (Ki) for each of the 9 ligands, thus validating the robustness of our model.

Docking of Thiowurtzine. The docking of thiowurtzine into the models of the five receptors (mu, kappa, delta, ORL1, and $\mathrm{Ca}_{\mathrm{v}}$ 1.2) was performed using the GOLD software. We used control drugs (tramadol, ketorolac, and diclofenac) as references. As tramadol is commercially available as a racemic mix $(1 R-2 R$ and $1 S-2 S)$, we separately tested each of the two enantiomers and reported their respective score. All the results are summarized in Table 4.

Table 4. Docking scores of thiowurtzine and control drugs against mu, kappa, delta, ORL1, and Cav 1.2 receptors.

\begin{tabular}{|c|c|c|c|c|c|}
\hline Drug & $\begin{array}{l}\text { GOLD score with } \\
\text { the mu receptor }\end{array}$ & $\begin{array}{l}\text { GOLD score with } \\
\text { the kappa receptor }\end{array}$ & $\begin{array}{l}\text { GOLD score with } \\
\text { the delta receptor }\end{array}$ & $\begin{array}{l}\text { GOLD score with } \\
\text { the ORL1 receptor }\end{array}$ & $\begin{array}{l}\text { GOLD score with } \\
\text { the } \mathrm{Ca}_{\mathrm{v}} 1.2 \text { recep- } \\
\text { tor }\end{array}$ \\
\hline Tramadol $1 S-2 S$ & 19,546 & 27,003 & 21,797 & 20,520 & 24,499 \\
\hline Tramadol $1 R-2 R$ & 19,188 & 28,349 & 20,435 & 19,272 & 23,597 \\
\hline Ketorolac & 19,529 & 26,150 & 23,640 & 19,467 & 22,065 \\
\hline Diclofenac & 20,823 & 31,603 & 24,274 & 17,567 & 24,154 \\
\hline Thiowurtzine & 8,465 & 2,730 & 6,407 & 2,153 & 15,562 \\
\hline
\end{tabular}

Note. The scores of the GOLD ${ }^{39}$ docking software using the Chemscore 4142 rescore function are displayed.

Interestingly, the docking scores of thiowurtzine are lower than those of the reference drugs for all the investigated receptors. However, these scores are high enough to unequivocally demonstrate an effective binding 
of thiowurtzine, especially with the mu, delta and $\mathrm{Ca}_{v}$ receptors. For the mu and delta receptors, the scores are about 2.5 to 4 times lower than those of tramadol, ketorolac or diclofenac. However, the animal experiments evidenced that the doses of thiowurtzine needed to be typically 5 times higher than those of tramadol $(20 \mathrm{mg} / \mathrm{kg}$ vs $100 \mathrm{mg} / \mathrm{kg})$ and diclofenac $(10 \mathrm{mg} / \mathrm{kg}$ vs $50 \mathrm{mg} / \mathrm{kg})$ to produce similar effects with the acetic acid writhing test (Table 1). The same ratio was also observed for the hot plate test (diclofenac $5 \mathrm{mg} / \mathrm{kg}$, thiowurtzine $25 \mathrm{mg} / \mathrm{kg}$, Table 2) to produce similar results. Aside from the typical bioavailability issues, the animal experiments are thus in excellent agreement with our docking results. The best docking pose for the thiowurtzine in complex with the model of the mu opioid receptor is displayed in Figure 1.

For the Cav receptor, the docking scores of thiowurtzine are much better than for any of the other investigated receptors (Table 4), and they are close to those of the other reference drugs (albeit being about 30\% lower). Consequently, thiowurtzine appears to be a significantly better ligand for the $\mathrm{Ca}_{\mathrm{v}}$ receptor than for any of the investigated opioid receptors. This is consistent with a complex mechanism of action, which could target at the same time the opioid receptors and the voltage-gated calcium channels.

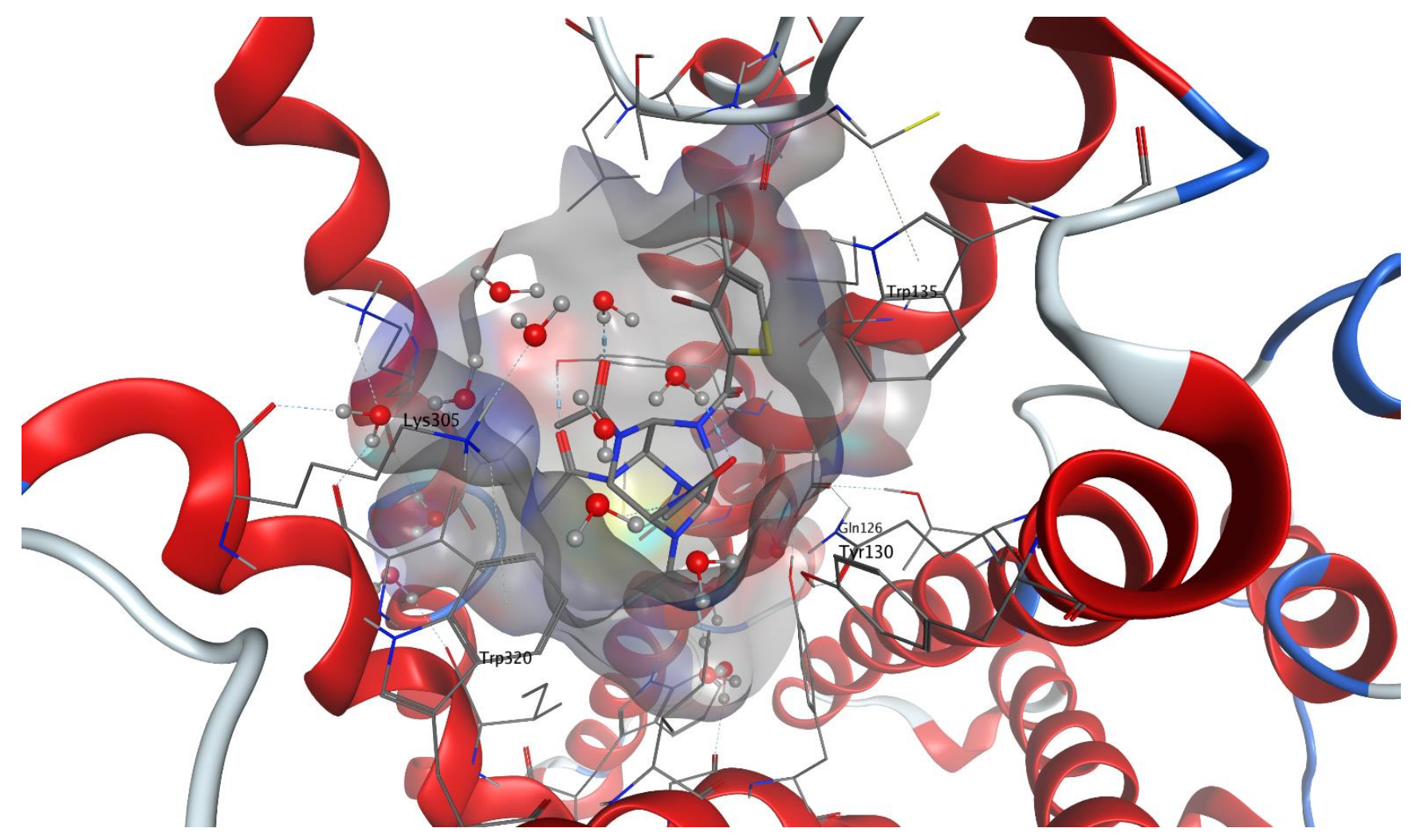

Figure 1. Molecular representation of the best docking pose of the thiowurtzine molecule interacting with the calculated model of the mu opioid receptor. Thiowurtzine is displayed as sticks, and the mu receptor with red ribbons. The water molecules are visible, as well as the molecular surface of the cavity surrounding the thiowurtzine molecule. The sidechains of the residues interacting with thiowurtzine are labelled and displayed as sticks as well.

Molecular Dynamics. In order to validate whether our hypothesis of thiowurtzine binding to the $\mathrm{Ca}_{\mathrm{v}} 1.2$ calcium channel was stable over time, molecular dynamics experiments were carried out for the receptor in presence of thiowurtzine. We used the best docking pose of thiowurtzine with the model of the $\mathrm{Ca}_{\mathrm{v}} 1.2$ calcium channel as a starting point. A lipid bilayer surrounding the calcium channel was generated with the MOE lipid generator. Water molecules were added, as well as $\mathrm{Na}+$ and $\mathrm{Cl}$ - ions in order to simulate a $0.1 \mathrm{M}$ ionic force, and the $\mathrm{pH}$ was set at 7.4. Standard Amber 14:EHT parameters were used for the molecular dynamics (MD). A quick minimization was performed prior to the start of the MD simulation. After a preliminary equilibration phase, a $200 \mathrm{~ns}$ molecular simulation was performed. A frame was saved every 200 ps, leading to a total number of 1,000 frames. The last frame of the simulation is displayed in Figure 2. 


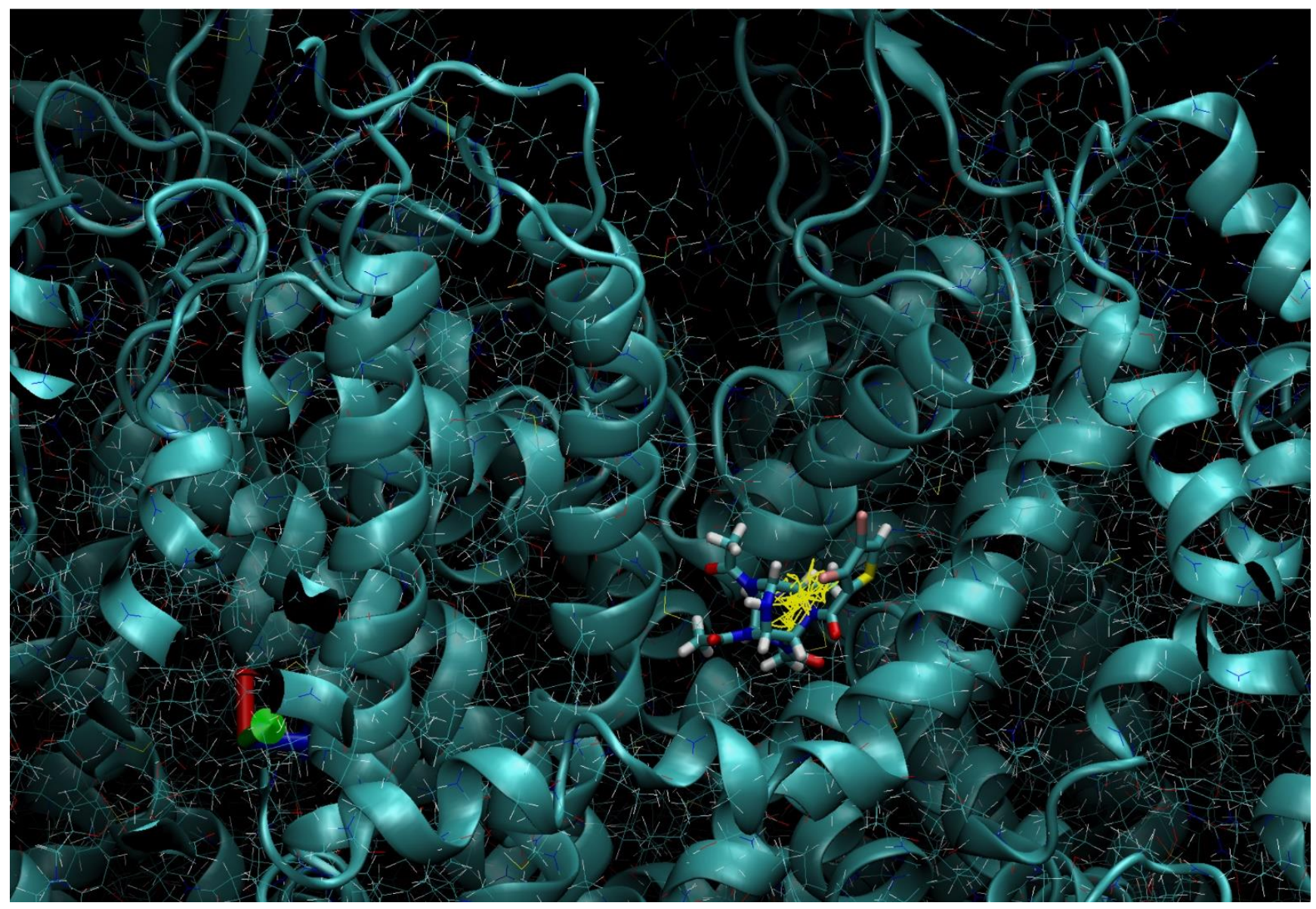

Figure 2. Molecular representation of the last frame of the $200 \mathrm{~ns}$ molecular dynamic simulation of thiowurtzine in complex with the model of the $\mathrm{Ca}_{\mathrm{v}}$ receptor. Thiowurtzine is displayed as sticks, and the $\mathrm{Ca}_{\mathrm{v}}$ calcium channel with teal ribbons. The trajectory of the thiowurtzine mass center throughout the entire simulation is displayed with yellow lines.

The molecular complex formed by thiowurtzine and the $\mathrm{Ca}_{\mathrm{v}}$ calcium channel model appeared to be extremely stable over time. In fact, thiowurtzine stayed within the interaction site during the 200 ns of the simulation, with only limited relative motions around its starting position at the beginning of the simulation. The full trajectory of the thiowurtzine mass center during the complete simulation is displayed with yellow sticks in Figure 2 and evidences a great stability of the complex over time. These results are in excellent agreement with the good docking scores previously obtained with the GOLD software for the thiowurtzine interacting with the model of the $\mathrm{Ca}_{\mathrm{v}}$ receptor (Table 4).

\section{CONCLUSION}

In summary, we provided the chemical synthesis, the biological evaluation and the in-silico target identification of a potent new hexazaisowurtzitane-based analgesic referred here as thiowurtzine. This non-addictive analgesic does not exhibit any of the NSAIDs typical adverse effects and may very well lead to new compounds of the same class with practical applications.

It is worth noting that the devised original method for the synthesis of 3,4-dibromothiophene carboxylic acid holds promise for further use, as it provides a quite high yield under mild synthesis conditions.
The experimental evidence (behavioral tests with thermal and chemical stimuli, and mechanical compression) demonstrates an analgesic effect of thiowurtzine through its inhibitory action on the peripheral and central mechanisms of development and maintenance of pain syndrome. These findings highlight a promising potential of the new compound as an analgesic against pain syndromes of different etiologies.

The software-based evaluation of thiowurtzine, which was validated by the animal studies, gave some interesting perspectives about the potential molecular receptors of thiowurtzine. We highlighted the role of the opioid receptors as primary targets, which confirmed the results of the experiments using thiowurtzine in conjunction with naloxone. However, the antinociceptive effect of thiowurtzine was not completely abolished by naloxone ${ }^{18}$, which suggests that the opioid analgesia pathway may not be the only component of the mechanism of action of thiowurtzine, and consequently, that there may be other receptors targeted as well.

Molecular comparisons with other drugs, associated with molecular modeling and molecular dynamics simulations allowed us to also consider voltage-gated calcium channels as potential targets. Interestingly, the possibility that calcium channel blockers might induce analgesia by reducing the release of neurotransmitters and thus 
increase morphine analgesia has been investigated and confirmed in several studies. ${ }^{34} 35363738$ Those results are consistent with thiowurtzine having a primary action on the central opioid system and suggest that this primary action may very well be potentiated by a secondary action on the voltage-gated calcium channels as well. These results were confirmed by the docking scores of thiowurtzine against the opioid and the calcium receptors. Those findings might provide a solid basis for the explanation of the complicated mechanism of action of thiowurtzine.

New rational design studies involving further chemical modifications of hexaazaizowurtzitane-derivatives are currently under way and might lead to the discovery of a whole new class of biologically active molecules of interest.

\section{EXPERIMENTAL SECTION}

General Methods. High-performance liquid chromatography (HPLC) was performed on an Agilent Technologies 1260 Infinity instrument with a $2.1 \times 15$-mm pre-column, Zorbax SB-18 sorbent, and $3 \mu \mathrm{m}$ fractions; $3.0 \times 150$ mm column, Zorbax SB-18 sorbent, $3.5 \mu \mathrm{m}$ fractions using gradient elution. Eluent A: $0.2 \%$ orthophosphoric acid solution, eluent $\mathrm{B}$ : acetonitrile. ${ }^{1} \mathrm{H}$ and ${ }^{13} \mathrm{C}$ NMR spectra were recorded on a Bruker AM-400 spectrometer operating at $400.13 \mathrm{MHz}$ for ${ }^{1} \mathrm{H}$ and at $100.61 \mathrm{MHz}$ for ${ }^{13} \mathrm{C}$; DMSO- $d_{6}$ was used as solvent. IR spectra were taken on a Infralum FT-801 spectrophotometer in $\mathrm{KBr}$ pellets (1 mg substance in $200 \mathrm{mg}$ potassium bromide) in a range from 4000 to $400 \mathrm{~cm}^{-1}$. The melting point was measured on a Stuart SMP 30 melting point apparatus.

Synthesis of $2,4,6,8,10,12$-hexabenzyl-2,4,6,8,10,12hexaazatetra-cyclo $\left[5,5,0,0^{3,11}, 0^{5,9}\right]$ dodecane (V). Into a stirred flask was put benzylamine $(170 \mathrm{~mL}, 1.56 \mathrm{~mol})$, distilled water $(130 \mathrm{~mL})$, acetonitrile $(1430 \mathrm{~mL})$ and $98 \%$ formic acid ( $5.4 \mathrm{~mL}$ ). Then, $40 \%$ aqueous glyoxal $(94.25 \mathrm{~g}$, $0.65 \mathrm{~mol}$ ) was added portionwise for $1 \mathrm{~h}$ at a temperature not above $20^{\circ} \mathrm{C}$. The reaction mixture was held at room temperature for $17 \mathrm{~h}$. The resultant crystalline product was collected by filtration and washed in-situ with cold acetonitrile. Yield: $121 \mathrm{~g}$ (76\% on a benzylamine basis). Mp: $145-150^{\circ} \mathrm{C}$.

For deresination, the resultant crude product was stirred in acetonitrile $(240-250 \mathrm{~mL})$ at $50^{\circ} \mathrm{C}$ for $15-20$ min, cooled to room temperature, filtered and washed with acetonitrile to furnish 115-118 g of the product (Mp: $150-153^{\circ} \mathrm{C}$ ) after drying. Calcd for $\mathrm{C}_{48} \mathrm{H}_{48} \mathrm{~N}_{6}(\%): 81.32 ; \mathrm{H}$ 6.82; N 11.85; found (\%): C 82.13; H 6.79; N 11.09. IR $\left(\mathrm{v} / \mathrm{cm}^{-1}\right): 3082,3061,3023,2923,2857,2823,1493,1452$, $1351,1323,1302,1244,1140,1072,987,898,835,733$, 699, 625. ${ }^{1} \mathrm{H}$ NMR (DMSO- $\left.d_{6}, \delta, \mathrm{ppm}\right): 3.48(\mathrm{~s}, 2 \mathrm{H}, \mathrm{CH}), 4.01$ (s, 4H, CH2), 4,04 (s, 4H, CH2), $4.15(\mathrm{~s}, 4 \mathrm{H}, \mathrm{CH}), 7.14-7.26$ (m, 30H, CHap).

Synthesis of 4,10-dibenzyl-2,6,8,12-tetraacetyl$\mathbf{2 , 4 , 6 , 8 , 1 0 , 1 2 - h e x a a z a t e t r a c y c l o}\left[5,5,0,0^{3,11}, 0^{5,9}\right]$ dodecane (VI). Into a 300-mL autoclave equipped with an electromagnetic stirrer and a hydrogen gas delivery system was loaded hexabenzylhexaazaisowurtzitane (10 g), bromobenzene (0.18-0.20 mL), a catalyst, and DMF (40 mL). Lastly, acetic anhydride $(15 \mathrm{~mL})$ was added, and the autoclave was closed. The autoclave was purged with hydrogen three times. Hydrogen was then supplied under 5-6 kgf $/ \mathrm{cm}^{2}$, stirring was turned on (550-600 rpm), and the whole was heated to $50-55^{\circ} \mathrm{C}$. The hydrogen absorption was controlled against the autoclave pressure drop. If the autoclave pressure went down below $2.5-2 \mathrm{kgf} / \mathrm{cm}^{2}$, hydrogen was again fed to $5-6 \mathrm{kgf} / \mathrm{cm}^{2}$.

After the process was complete (an autoclave pressure drop of $0.1-0.2 \mathrm{kgf} / \mathrm{cm}^{2}$ within $1 \mathrm{~h}$ ), the heating was turned off, cold water was poured into the bath, and the reactor was cooled to $20-25^{\circ} \mathrm{C}$.

Hydrogen depressurization was then performed, and the product suspension with the catalyst was filtered. The mixture of dibenzyltetraacertylhexaazaisowurtzitane (DBTA) and catalyst was washed with ethanol $(3 \times 10 \mathrm{~mL})$, squeezed and air-dried to furnish DBTA not allowing for the catalyst weight. Yield: $5.8-6 \mathrm{~g}(80-83 \%)$. Calcd for $\mathrm{C}_{28} \mathrm{H}_{32} \mathrm{~N}_{6} \mathrm{O}_{4}$ (\%): C 65.10; $\mathrm{H}$ 6.24; N 16.27; 0 12.39; found (\%): C 64.79; H 6.18; N 16.25. IR (v/ $\left.\mathrm{cm}^{-1}\right): 3083,3044$, $3022,3005,2876,2829,1687,1650,1455,1412,1358$, 1319, 1300, 1239, 1147, 1068, 985, 893, 834, 730, 687, 627. ${ }^{1} \mathrm{H}$ NMR (DMSO- $\left.d_{6}, \delta \mathrm{ppm}\right): 1.85-1.95(\mathrm{~m}, 12 \mathrm{H}, \mathrm{CH} 3)$, 4.09 (s, 4H, CH2), 5.71 (br.s, 4H, CH), 6.51 (br.s 4H, CH), 7.37-7.49 (m, 10H, CHap).

Synthesis of 2,6,8,12-tetraacetyl-2,4,6,8,10,12-hexaazatetracyclo $\left[5,5,0,0^{3,11}, 0^{5,9}\right]$ dodecane (III). Into an autoclave was loaded DBTA (25 g), 5 \% Pd/C (5 g) and $50 \%$ acetic acid $(150 \mathrm{~mL})$. The autoclave was closed, purged 3 times with nitrogen and 2 times with hydrogen. Hydrogen was then fed at $5 \mathrm{kgf} / \mathrm{cm}^{2}$ and stirring was turned on. The reaction was carried out at $70-75^{\circ} \mathrm{C}$ for 3 $\mathrm{h}$. The catalyst was then filtered off, and the reaction mixture was evaporated in a rotary evaporator until it was viscous. To the evaporated mixture was added alcohol (150-200 mL) and the whole was stirred for 15-20 min. The crystalline product was collected by filtration and airdried to give tetraacetylhexaazaisowurtzitane (TA). Yield: $15 \mathrm{~g}$ (92\%), purity $98 \%$ (as per HPLC). Mp: $360^{\circ} \mathrm{C}$ (decomposition). Calcd for $\mathrm{C}_{14} \mathrm{H}_{20} \mathrm{~N}_{6} \mathrm{O}_{8}$ (\%): C 49.99; $\mathrm{H} 5.99$; $\mathrm{N}$ 24.99; O 19.03; found (\%): C 50.16; H 6.04; N 24.72. (IR $\mathrm{v} / \mathrm{cm}^{-1}$ ): 3369, 3329, 3047, 3019, 2931, 1659, 1402, 1359, 1293, 1255, 1140, 1111, 1019, 974, 909, 801, 710, 609, 509. ${ }^{1} \mathrm{H}$ NMR (DMSO- $\left.d_{6}, \delta \mathrm{ppm}\right): 1.94-2.07(\mathrm{~m}, 12 \mathrm{H}$, CH3CO), 4.59-4.99 (m, 2H, NH), 5.29 (br.s, 2H, CH), 5.99$6.23(\mathrm{~m}, 4 \mathrm{H}, \mathrm{CH})$.

Synthesis of 3,4-dibromothiophene carboxylic acid (IV): Into a round-bottom flask was put thiophene $(48 \mathrm{~mL}, 0.6$ $\mathrm{mol}$ ), chloroform (24 mL), and bromine (128 mL, $2.4 \mathrm{~mol}$ ) was slowly added dropwise. The dosing time was $4 \mathrm{~h}$. In the beginning of the dosing, the solution was observed to be decolored and hydrogen bromide to evolve vigorously. Hydrogen bromide was entrapped and absorbed with a $20 \% \mathrm{NaOH}$ solution. After dosing was completed, the reaction mixture was cooled on ice bath and held for $12 \mathrm{~h}$.

Upon completion of holding, to the reaction mixture was added chloroform $(20 \mathrm{~mL})$ and the whole was heated on silicone bath at $85^{\circ} \mathrm{C}$, and a $15 \% \mathrm{KOH}$ solution in ethanol was added. The mixture was refluxed for $3 \mathrm{~h}$ with vigorous stirring, then cooled down and poured out onto ice (400 g). After holding for $1 \mathrm{~h}$, the product was filtered off, washed with water and air-dried. 
To a 1-L flask fitted with a distiller was added zinc pow$\operatorname{der}(180.6 \mathrm{~g}, 2.76 \mathrm{~mol})$ in water $(240 \mathrm{~mL})$, and glacial acetic acid (180 mL, $5.2 \mathrm{~mol})$ was then added. The reaction mixture was heated to boil, and the crude product was added in a few portions. The distilled organic fraction was washed with water and then dried over $\mathrm{MgSO}_{4}$ to yield 3,4dibromothiophene as a colorless liquid. Yield: $74.07 \mathrm{~g}$ (51\%).

To a mixture of the resultant 3,4-dibromothiophene $(0.024 \mathrm{~mol})$ and dichloromethyl methyl ether $(2.98 \mathrm{~g}, 2.35$ $\mathrm{mL}, 0.026 \mathrm{~mol})$ in dry dichloromethane $(15 \mathrm{~mL})$ was added TiCl4 (7.59 g, $4.39 \mathrm{~mL}, 0.04 \mathrm{~mol}$ ) with stirring at $12^{\circ} \mathrm{C}$ for $40-50 \mathrm{~min}$. The reaction mixture was stirred for $1 \mathrm{~h}$, and water ( $30 \mathrm{~mL}$ ) was added drop by drop within 15 $\mathrm{min}$. After $30 \mathrm{~min}$, the layers were separated, and the water layer was extracted with dichloromethane $(3 \times 30 \mathrm{~mL})$. The combined extract was dried over $\mathrm{MgSO}_{4}$ and evaporated. The product was recrystallized from heptane, dried and used in the subsequent stage.

The resultant 3,4-dibromo-2-thiophene-aldehyde $(47,1$ $\mathrm{g}, 0.174 \mathrm{~mol})$ was dissolved in acetone $(550 \mathrm{~mL})$. A potassium permanganate (37.8 g) solution in distilled water $(720 \mathrm{~mL})$ was prepared separately by heating.

To the aldehyde acetone solution was added potassium permanganate in portions of $15-20 \mathrm{~mL}$ at not above $20^{\circ} \mathrm{C}$. The whole was held for 3-5 min after adding each portion. The dosing was stopped after the solution turned a stable pink color. The resultant suspension was decolored by adding a $10 \%$ sodium sulfite solution. The reaction mixture was filtered off of $\mathrm{MnO}_{2}$ and washed with water.

The filtrate was evaporated by half and acidified with $\mathrm{HCl}$ until pH was less than 2 . The product was collected by filtration, washed with water and then recrystallized from dichloroethane to afford 3,4-dibromothiophene carboxylic acid. Yield: $42.29 \mathrm{~g}$ (85\%). Mp: $205-207^{\circ} \mathrm{C}$. Calcd for $\mathrm{C}_{5} \mathrm{H}_{2} \mathrm{Br}_{2} \mathrm{O}_{2} \mathrm{~S}$ (\%): C 21.00; $\mathrm{H} 0.70 ; \mathrm{Br} 55.89 ; 0$ 11.19; S 11.21l found: (\%): C 21.09; H 0.69; S 11.24. IR (v/cm-1): 3102, 3098, 1663, 1478, 1389, 1321, 1123, 920, 857, 784, 685. ${ }^{1} \mathrm{H}$ NMR (DMSO- $\left.d_{6}, \delta \mathrm{ppm}\right): 7.44(\mathrm{c}, 1 \mathrm{H}, \mathrm{CH}), 10.93$ (br.s, 1H, OH).

Synthesis of 3,4-dibromothiophenecarbonyl chloride (II). 3,4-dibromothiophene carboxylic acid (10 g, $0.035 \mathrm{~mol}$ ) was put into thionyl chloride $(50 \mathrm{~mL})$ and heated to the boiling point of thionyl chloride. The mixture was held at the same temperature for $1 \mathrm{~h}$, then cooled down and evaporated in a rotary evaporator. Yield: $9.2 \mathrm{~g}$ (86\%). Mp was not measured because the product was immediately used in further reaction.

Synthesis of 4-(3,4-dibromothiophenecarbonyl)2,6,8,12-tetraacetyl-2,4,6,8,10,12-hexaazatetracyclo[5,5,0,03,11,05,9]dodecane (I). To a solution of chloroanhydride $\mathrm{V}(9.2 \mathrm{~g}, 0.03 \mathrm{~mol})$ in dry acetonitrile $(60 \mathrm{~mL})$ was added 2,6,8,12-tetraacetyl-2,4,6,8,10,12-hexaazatetracyclo[5,5,0,03,11,05,9]dodecane $(5.04 \mathrm{~g}, 0.015 \mathrm{~mol})$. The resultant mixture was refluxed for $2 \mathrm{~h}$ and then cooled down, and the precipitated product was collected by filtration and washed 2 times with acetonitrile.

The dried creamy-colored sediment was recrystallized from $70 \%$ (by vol.) aqueous ethanol. The resultant product was washed with water 3 times and air-dried to furnish 4-(3,4-dibromothiophenecarbonyl)-2,6,8,12- tetraacetyl-2,4,6,8,10,12-hexaazatetracy-

clo $\left[5,5,0,0^{3,11}, 0^{5,9}\right]$ dodecane as a colorless crystalline product with an assay of 99\% (as per HPLC). Yield: $7.19 \mathrm{~g}$ (79.4\%). MP: $332-334^{\circ} \mathrm{C}$. Calcd for $\mathrm{C}_{19} \mathrm{H}_{20} \mathrm{Br}_{2} \mathrm{~N}_{6} \mathrm{O}_{5} \mathrm{~S}$ (\%): C 37.76; H 3.34; Br 26.45; N 13.91; 0 13.24; S 5.31; found (\%): C 37.68; H 3.24; N 13.82; S 5.37. IR $\left(\mathrm{v} / \mathrm{cm}^{-1}\right): 3287$, $3119,3005,1657,1504,1425,1356,1323,1289,1250$, $1162,1045,984,893,878,742,715,623 .{ }^{1} \mathrm{H}$ NMR (DMSO$\left.d_{6}, \delta \mathrm{ppm}\right): 1.85-2.15(\mathrm{~m}, 12 \mathrm{H}, \mathrm{CH} 3 \mathrm{CO}), 4.75-5.12(\mathrm{~m}, 1 \mathrm{H}$, $\mathrm{NH})$, 5.45-5.67 (m, 2H, CH), 5.92-6.85 (m, 4H, CH), 8.08$8.18(\mathrm{~m}, 1 \mathrm{H}, \mathrm{CH}) .{ }^{13} \mathrm{C}$ NMR (DMSO- $\left.d_{6}, \delta \mathrm{ppm}\right): 21.16,21,47$, 22.19, 22.43, 22.60, 22.90 (C, СH3, СН3CO); 65.07, 67.70, $69.3,70.31,71.3,73.12$ (C, CH); 113.13, 114.63 (C, arom.); 127.5 (C, CH, arom.); 132.14 (C, arom.); 162.63, 162.78 (C, CO); 166.7, 167.1, 167.5, 167.9 (C, CO, CH3CO).

Animals. The experiments were carried out on adult inbred male CBA mice $(n=24)$, outbred male stock CD1 mice $(n=45)$, outbred female stock CD1 mice $(n=40)$ and outbred male stock CD rats $(n=74)$ (1st category conventional animals). The animals were obtained from the Department of Experimental Biomodelling, E. D. Goldberg Research Institute of Pharmacology and Regenerative Medicine (animal health certificate). Animal maintenance and experimental design were approved by the Bioethics Committee of the E. D. Goldberg Research Institute of Pharmacology and Regenerative Medicine (JACUC protocol No. 96092015) and complied with the directive 2010/63/EU of the European Parliament and the Council of the European Union on the Protection of Animals used for Scientific Purposes, Order No. 199n of the Ministry of Health of Russian Federation (August 1, 2016).

Study design. When the maximum possible single injection volume of thiowurtzine was used, LD50 (or animal death) was not achieved. The compound was daily administered per os through a probe in a dose range of 50-200 $\mathrm{mg} / \mathrm{kg}$ (mice) and 25-300 mg/kg (rats) for 1-4 days (Tables $1-3$ ), the last administration was carried out $1 \mathrm{~h}$ prior to the pain sensitivity test. The reference drugs were: NSAID diclofenac (Hemofarm), administered orally in a dose of $10 \mathrm{mg} / \mathrm{kg}$ in a volume of $0.2 \mathrm{ml} /$ mouse, in a dose of $5 \mathrm{mg} / \mathrm{kg}$ in a volume of $0.5 \mathrm{ml} / \mathrm{rat}$, NSAID ketorolac (Dr. Reddy's Laboratories Ltd..), administered orally in a dose of $10 \mathrm{mg} / \mathrm{kg}$, Tramadol (Organic), administered in a dose of $20 \mathrm{mg} / \mathrm{kg}$ via a probe in the form of a solution in purified water in a volume of $0.2 \mathrm{ml} /$ mouse. The suggested doses of reference drugs matched the average therapeutic doses in humans. ${ }^{43}$ The animals of the negative control group received vehicle (water-Tween mixture) in an equivalent volume via the same route.

Animal methods. The analgesic activity of thiowurtzine was assessed in behavioral tests with thermal and chemical exposures, in Randall-Selitto test with mechanical compression of normal paw pad and with formalin edema.

Hot plate test. The hot plate test is basic in analgesic activity assessment studies, it involves behavioral responses to pain, controlled by cortical and subcortical structures of brain. ${ }^{44}$ One hour after compound administration, the test was performed using Hot Plate Analgesia Meter (Columbus Instruments). The rats were placed on a plate heated to $54.0 \pm 0.5^{\circ} \mathrm{C}$, after which pain reaction latency was recorded (licking front and hind paw pads). 
Analgesic activity was measured by the mean latency in the group and percentage of the pain response inhibition (\%PRI), according to the formula: (Tcontrol - Texperiment)/Tcontrol $\times 100 \%$, where $\mathrm{T}$ is pain response latency in the corresponding group.

Acetic acid writhing test. The acetic acid writhing test is aimed at assessment of acute visceral deep pain. ${ }^{43} 4546$ 47448 . The specific response to pain (writhing) was caused by intraperitoneal injection of $0.75 \%$ acetic acid solution in a volume of $0.1 \mathrm{ml} / 10 \mathrm{~g}$ body weight. The analgesic effect was evaluated by the ability of the compound (within 20 min after the injection) to reduce the number of writhings (in \%) in comparison with the control group.

Randall-Selitto test. The Randall-Selitto test (Randall and Selitto, 1957), intended to serve as a tool to assess the effect of analgesic agents on the response thresholds to mechanical pressure stimulation, usually using by a number of investigators to evaluate inflammatory painful responses. ${ }^{43} 4546474448$ An Ugo Basile electronic device based on the Randall-Selitto principle, which allows testing pain in a quantitative manner by pressuring hind limbs of animals, has been used. Hyperalgesia was induced by subcutaneous injection of $2 \%$ formalin solution in a volume of $50 \mu \mathrm{l}$ intraplantarily into the right hind paw pad after one hour compound administration. The Randall-Selitto test was performed twice on each individual one and four hours after compound administration on the left hind paw pad and in first 1-5 min and 40-50 min after the inducing of hyperalgesia on the right hind paw pad. Analgesic activity was evaluated by the ability of the compound to change the response threshold in comparison with the positive and negative control groups.

The rats were sacrificed by $\mathrm{CO} 2$ inhalation, the mice were killed by craniocervical dislocation.

Statistical processing. Statistical processing of the results was performed using ANOVA (Statistica 6.0). For all data, the mean (X) and standard error of the mean (m) were calculated (shown in tables); nis the number of variants in the group. Differences in the studied parameters were assessed with the nonparametric Mann-Whitney U test for testing hypotheses about the homogeneity of the means. The differences were significant at $\mathrm{p}<0.05$.

Homology Modeling. The mu, kappa, delta and ORL1 opioid receptors were constructed using the corresponding human sequences (respective UniProtKB identifier P35372, P41145, P41143, and P4114) and the online software I-TASSER (Iterative Threading ASSEmbly Refinement) from the Zhang Lab. ${ }^{40}$ This iterative modeling software can use several different partial templates when no single valid template is available. Five models for each receptor were computed using the software default options, and the five best ones were further imported into the MOE software to be checked, charged, and minimized using the AMBER 14:ETH force field.

The homology model for the $\mathrm{Ca}_{\mathrm{v}} 1.2$ calcium channel was built using the UniProtKB sequence Q13936 (isoform 1) of the human voltage-gated calcium channel subunit $\alpha_{1 c}$ $\mathrm{Ca}_{\mathrm{v}} 1.2$ and the PDB structure 6JP5 of the rabbit Cav1.1 / nifedipine complex (resolution $2.90 \AA$ ) as a template. The alignment statistics were calculated as follows: $66.4 \%$ identity, $75.3 \%$ similarity, $4.7 \%$ gaps for a total length of
1359 residues. Prior to the homology modeling, the geometry of all the molecules, bonds, and charges of the PDB structure 6JP5 were checked using the Structure Preparation tool of the Molecular Operating Environment software (MOE 2020, Chemical Computing Group, Köln, Germany) and minimized with the Amber 14:EHT forcefield implemented within the MOE software. The homology model was generated using the $\alpha_{1 \mathrm{c}}$ subunit as a template and the MOE standard parameters in the Protein / Homology Model module. Several loops (215-232, 446-509, 776892, 941-962, and 1326-1374) were added as the corresponding residues did not exist in the template, but their structure and position were checked and none of them was involved in the interaction with nifedipine.

Docking. The docking procedures were performed with the GOLD ${ }^{39}$ software (version 2020.3), using the HERMES 49 interface (CCDC, Cambridge Crystallographic Data Center) and the implemented GOLD Wizard. We used the GOLD standard parameters for the docking, with the exploration of a spherical site (10 A radius) centered on the previously co-crystallized ligands. The Genetic algorithm (GA) parameter was set to a number of 200 poses with the activation of the early stop function. We used the ASP (Astex Scoring Potential) fitness function ${ }^{50}$ for calculating the docking scores, and the Chemscore scoring function ${ }^{41}$ 42 for the rescore of the results.

Molecular Dynamics. Molecular Dynamics simulations were performed for the homology model of the $\mathrm{Ca}_{\mathrm{v}} 1.2 \mathrm{cal}$ cium channel in presence of thiowurtzine using the Amber 14:EHT force field implemented in the MOE software. A lipid bilayer surrounding the calcium channel and composed of DOPE (1,2-Dioleoyl-sn-glycero-3-phosphoethanolamine) and DOPG (1,2-Dioleoyl-sn-glycero-3-phosphorac-1-glycerol)-with a respective ratio of 3:1 was generated with the MOE lipid generator, using the PACKMOLMemgen approach. 515253 TIP3P water molecules 5455 were added, as well as $\mathrm{Na}+$ and $\mathrm{Cl}$ - ions in order to simulate a $0.1 \mathrm{M}$ ionic force, and $\mathrm{pH}$ was set at 7.4. Standard Amber 14:EHT parameters were used for the molecular dynamics. A quick minimization was performed prior to the start of the MD simulations. The geometry of all the molecules, bonds, and charges were then checked using the Structure Preparation tool in MOE, in order to start the molecular simulations. After a preliminary equilibration phase, a 200 ns molecular simulation was performed. A frame was saved every 200 ps, leading to a total number of 1,000 frames.

\section{ASSOCIATED CONTENT}

\section{Supporting Information}

The Supporting Information contains the ${ }^{1} \mathrm{H}$ and ${ }^{13} \mathrm{C}$ NMR spectra for compounds I, IV, VIII and IX, IR spectra for I. It is available free of charge on the ACS Publications website: http://pubs.acs.org...

The structural PDB data for the different models of the receptors (mu, kappa, delta, ORL1, and $\mathrm{Ca}_{\mathrm{v}} 1.2$ ) are also available.

\section{AUTHOR INFORMATION}

Corresponding Author 
${ }^{*}$ Corresponding author. Email address: raphael.terreux@univ-lyon1.fr (R. Terreux), imbiri@rambler.ru (D.A. Kulagina)

\section{Author Contributions}

\# S.A. and S.M. contributed equally to this work as first coauthors. The manuscript was written through contributions of all authors. All authors have given approval to the final version of the manuscript.

\section{Notes}

The authors declare that they have no competing financial interests.

\section{ACKNOWLEDGMENT}

The authors would like to thank Johnny Truong for his work on the homology model of the $\mathrm{Ca}_{\mathrm{v}} 1.2$ calcium channel and the subsequent docking of thiowurtzine.

\section{ABBREVIATIONS}

GOLD software, Genetic Optimization for Ligand Docking software; MD, Molecular Dynamics; MOE software, Molecular Operating Environment software; NSAIDs, Non-Steroidal Anti-Inflammatory Drugs; ORL1, Opioid Like Receptor 1; vs, versus.

\section{REFERENCES}

(1) Varrassi, G. Severe Chronic Pain - the Reality of Treatment in Europe. Current Medical Research and Opinion 2011, 27 (10), 2063-2064 https://doi.org/10.1185/03007995.2011.619426.

(2) Piper, B. J.; Shah, D. T.; Simoyan, O. M.; McCall, K. L.; Nichols, S. D. Trends in Medical Use of Opioids in the U.S., 20062016. American Journal of Preventive Medicine 2018, 54 (5), 652660. https://doi.org/10.1016/j.amepre.2018.01.034.

(3) Cawich, S. O.; Deonarine, U.; Harding, H. E.; Dan, D.; Naraynsingh, V. Chapter 46 - Cannabis and Postoperative Analgesia. In Handbook of Cannabis and Related Pathologies; Preedy, V. R., Ed.; Academic Press: San Diego, 2017; pp 450-458. https://doi.org/10.1016/B978-0-12-800756-3.00052-1.

(4) Karateev, A. E.; Nasonov, E. L.; Yakhno, N. N.; Ivashkin, V. T.; Chichasova, N. V.; Alekseeva, L. I.; Karpov, Y. A.; Evseev, M. A.; Kukushkin, M. L.; Danilov, A. B.; Vorobyeva, O. V.; Amelin, A. V.; Novikova, D. S.; Drapkina, O. M.; Kopenkin, S. S.; Abuzarova, G. R. Clinical guidelines «Rational use of nonsteroidal anti-inflammatory drugs (NSAIDs) in clinical practice». Modern Rheumatology Journal 2015, 9 (1), 4-23. https://doi.org/10.14412/19967012-2015-1-4-23.

(5) Argoff, C. E.; Albrecht, P.; Irving, G.; Rice, F. Multimodal Analgesia for Chronic Pain: Rationale and Future Directions. Pain Med 2009, 10 Suppl 2, S53-66. https://doi.org/10.1111/j.15264637.2009.00669.x.

(6) Pogodin, P. V.; Lagunin, A. A.; Filimonov, D. A.; Nicklaus, M. C.; Poroikov, V. V. Improving (Q)SAR Predictions by Examining Bias in the Selection of Compounds for Experimental Testing. SAR QSAR Environ Res 2019, 30 (10), 759-773. https://doi.org/10.1080/1062936X.2019.1665580.

(7) Macarron, R.; Banks, M. N.; Bojanic, D.; Burns, D. J.; Cirovic, D. A.; Garyantes, T.; Green, D. V. S.; Hertzberg, R. P.; Janzen, W. P.; Paslay, J. W.; Schopfer, U.; Sittampalam, G. S. Impact of HighThroughput Screening in Biomedical Research. Nature Reviews Drug Discovery 2011, 10 (3), 188-195. https://doi.org/10.1038/nrd3368.

(8) Singh, N.; Chaput, L.; Villoutreix, B. O. Virtual Screening Web Servers: Designing Chemical Probes and Drug Candidates in the Cyberspace. Brief Bioinform 2020. https://doi.org/10.1093/bib/bbaa034.

(9) Крылова, С. Г.; Амосова, Е. Н.; Зуева, Е. П.; Разина, Т. Г.; Рыбалкина, О. Ю.; Лопатина, К. А.; Сысолятин, С. В.; Калашников, А. И.; Малыхин, В. В.; Дыгай, А. М.; Жданов, В. В.; Ворожцов, А. Б.; Жуков, А. С. 4-(3,4-Dibromothiophene Carbonyl)-2,6,8,12-Tetraacetyl-2,4,6,8,10,12-Hexaazatetracyclo[5,5,0,03,11,05,9]Dodecane as Analgesic Agent and Method for Production Thereof. RU2565766C1, October 20, 2015.

(10) Solovev, V. N. [Effect of nitroglycerin and menthol on vascular dilatation]. Klin Med (Mosk) 1949, 27 (3), 57-62.

(11) Lepow, H.; Turner, R. A. Peripheral Vasodilatation in Response to Controlled-Release Nitroglycerin. Southwest Med 1966, 47 (7), 190-192.

(12) Durlach, J.; Lemerre, L.; Lepage, F. [Treatment of premenstrual syndrome $\&$ pelvic pain syndrome with sugar-coated enteric tablets of potassium nitrate]. Rev Fr Gynecol Obstet 1958, 53 (1), 17-24.

(13) Collins, J. F.; Gingold, J.; Stanley, H.; Simring, M. Reducing Dentinal Hypersensitivity with Strontium Chloride and Potassium Nitrate. Gen Dent 1984, 32 (1), 40-43.

(14) Nair, U. R.; Sivabalan, R.; Gore, G. M.; Geetha, M.; Asthana, S. N.; Singh, H. Hexanitrohexaazaisowurtzitane (CL-20) and CL-20-Based Formulations (Review). Combust Explos Shock Waves 2005, 41 (2), 121-132. https://doi.org/10.1007/s10573005-0014-2.

(15) T. G. Tolstikova, E. A. Morozova, S. V. Sysolyatin, A. I. Kalashnikov, Y. I. Zhukova, V. N. Surmachev. Synthesis and Biological Activity of the Derivatives of 2,4,6,8,10,12-Hexaazatetracyclo[5.5.0.03,11.05,9]Dodecane. Chemistry for Sustainable Development 2010, No. 4, 431-436.

(16) Sysolyatin, S. V.; Lobanova, A. A.; Chernikova, Y. T.; Sakovich, G. V. Methods of Synthesis and Properties of Hexanitrohexaazaisowurtzitane. Russ. Chem. Rev. 2005, 74 (8), 757. https://doi.org/10.1070/RC2005v074n08ABEH001179.

(17) Menke, K. Organic Chemistry of Explosives, J. P. Agrawal, R. D. Hodgson. Propellants, Explosives, Pyrotechnics 2007, $32 \quad$ (2), 182-182. https://doi.org/10.1002/prep.200790002.

(18) Krylova, S. G.; Povet'eva, T. N.; Zueva, E. P.; Suslov, N. I.; Amosova, E. N.; Razina, T. G.; Lopatina, K. A.; Rybalkina, O. Yu.; Nesterova, Yu. V.; Afanas'eva, O. G.; Kiseleva, E. A.; Sysolyatin, S. V.; Kulagina, D. A.; Zhdanov, V. V. Analgesic Activity of Hexaazaisowurtzitane Derivatives. Bull Exp Biol Med 2019, 166 (4), 461-465. https://doi.org/10.1007/s10517-019-04372-9.

(19) Lopatina, К. А.; Александровна, Л. К.; Bryushinina, O. S.; Сергеевна, Б. O.; Gurto, R. V.; Владимирович, Г. P.; Krylova, S. G.; Геннадьевна, К. C.; Zuzkova, Y. G.; Геннадьевна, 3. Ю.; Kulagina, D. А.; Александровна, К. Д.; Safonova, Е. А.; Андреевна, C. E.; Zueva, Е. P.; Петровна, 3. Е.; Sysolyatin, S. V.; Викторович, C. C. Some pharmacokinetics aspects of new analgetics from hexaazaisiowuritsitane class in rats. Reviews on Clinical Pharmacology and Drug Therapy 2019, 17 (4), 51-56. https://doi.org/10.17816/RCF17451-56.

(20) Lopatina, K.; Krylova, S.; Safonova, E.; Zueva, E.; Kulagina, D.; Churin, A.; Fomina, T.; Sysolyatin, S. A New Analgesic Agent Based on Hexaazaisowurzitan: Feasibility of Using in Managing Patients with Cancer. Siberian journal of oncology 2020, 19, 76-81. https://doi.org/10.21294/1814-4861-2020-19-2-76-81.

(21) Lin, G.; Tsai, H.-J.; Tsai, Y.-H. Cage Amines as the Stopper Inhibitors of Cholinesterases. Bioorganic \& Medicinal Chemistry Letters 2003, 13 (17), 2887-2890. https://doi.org/10.1016/S0960-894X(03)00599-7.

(22) Sample Size Software | Power Analysis Software | PASS | NCSS.com https://www.ncss.com/software/pass/.

(23) Bellamy, A. J. Reductive Debenzylation of Hexabenzylhexaazaisowurtzitane. Tetrahedron 1995, 51 (16), 47114722. https://doi.org/10.1016/0040-4020(95)00155-2.

(24) Kalashnikov, A. I.; Sysolyatin, S. V.; Sakovich, G. V.; Surmacheva, I. A.; Surmachev, V. N.; Lapina, Yu. T. Debenzylation of 
2,6,8,12-Tetraacetyl-4,10-Dibenzyl-2,4,6,8,10,12-Hexaazatetracyclo[5.5.0.03,11.05,9]Dodecane. Russ Chem Bull 2009, 58 (10), 2164-2168. https://doi.org/10.1007/s11172-009-0295-9.

(25) Ananikov, V. P.; Khemchyan, L. L.; Ivanova, Y. V.; Bukhtiyarov, V. I.; Sorokin, A. M.; Prosvirin, I. P.; Vatsadze, S. Z.; Medved'ko, A. V.; Nuriev, V. N.; Dilman, A. D.; Levin, V. V.; Koptyug, I. V.; Kovtunov, K. V.; Zhivonitko, V. V.; Likholobov, V. A.; Romanenko, A. V.; Simonov, P. A.; Nenajdenko, V. G.; Shmatova, O. I.; Muzalevskiy, V. M.; Nechaev, M. S.; Asachenko, A. F.; Morozov, O. S.; Dzhevakov, P. B.; Osipov, S. N.; Vorobyeva, D. V.; Topchiy, M. A.; Zotova, M. A.; Ponomarenko, S. A.; Borshchev, O. V.; Luponosov, Y. N.; Rempel, A. A.; Valeeva, A. A.; Stakheev, A. Y.; Turova, O. V.; Mashkovsky, I. S.; Sysolyatin, S. V.; Malykhin, V. V.; Bukhtiyarova, G. A.; Terent'ev, A. O.; Krylov, I. B. Development of New Methods in Modern Selective Organic Synthesis: Preparation of Functionalized Molecules with Atomic Precision. Russ. Chem. Rev. 2014, 83 (10), 885-985. https://doi.org/10.1070/RC2014v83n10ABEH004471.

(26) Lewanowitsch, T.; Irvine, R. J. Naloxone and Its Quaternary Derivative, Naloxone Methiodide, Have Differing Affinities for $\mu, \delta$, and $\kappa$ Opioid Receptors in Mouse Brain Homogenates. Brain Research 2003, 964 (2), 302-305. https://doi.org/10.1016/S0006-8993(02)04117-3.

(27) Wishart, D. S.; Feunang, Y. D.; Guo, A. C.; Lo, E. J.; Marcu, A.; Grant, J. R.; Sajed, T.; Johnson, D.; Li, C.; Sayeeda, Z.; Assempour, N.; Iynkkaran, I.; Liu, Y.; Maciejewski, A.; Gale, N.; Wilson, A.; Chin, L.; Cummings, R.; Le, D.; Pon, A.; Knox, C.; Wilson, M. DrugBank 5.0: A Major Update to the DrugBank Database for 2018. Nucleic Acids Research 2018, 46 (D1), D1074-D1082. https://doi.org/10.1093/nar/gkx1037.

(28) Zamponi, G. W.; Striessnig, J.; Koschak, A.; Dolphin, A. C. The Physiology, Pathology, and Pharmacology of Voltage-Gated Calcium Channels and Their Future Therapeutic Potential. Pharmacol Rev 2015, 67 (4), 821-870. https://doi.org/10.1124/pr.114.009654.

(29) Gou, X.; Yu, X.; Bai, D.; Tan, B.; Cao, P.; Qian, M.; Zheng, X.; Chen, L.; Shi, Z.; Li, Y.; Ye, F.; Liang, Y.; Ni, J. Pharmacology and Mechanism of Action of HSK16149, a Selective Ligand of A2 $\delta$ Subunit of Voltage-Gated Calcium Channel with Analgesic Activity in Animal Models of Chronic Pain. J Pharmacol Exp Ther 2020. https://doi.org/10.1124/jpet.120.000315.

(30) Bourinet, E.; Zamponi, G. W. Voltage Gated Calcium Channels as Targets for Analgesics. Curr Top Med Chem 2005, 5 (6), 539-546. https://doi.org/10.2174/1568026054367610.

(31) Weiss, N.; Waard, M. de. [Voltage-dependent calcium channels at the heart of pain perception]. médecine/sciences 2006, 22 (4), 396.

(32) Todorovic, S. M.; Meyenburg, A.; Jevtovic-Todorovic, V. Mechanical and Thermal Antinociception in Rats Following Systemic Administration of Mibefradil, a T-Type Calcium Channel Blocker. Brain Res 2002, 951 (2), 336-340. https://doi.org/10.1016/s0006-8993(02)03350-4.

(33) Todorovic, S. M.; Pathirathna, S.; Meyenburg, A.; Jevtovic-Todorovic, V. Mechanical and Thermal Anti-Nociception in Rats after Systemic Administration of Verapamil. Neurosci Lett 2004, $360 \quad$ (1-2), 57-60. https://doi.org/10.1016/j.neulet.2004.02.049.

(34) Feliks, K. B.; Wrońska, D. Voltage-Gated Calcium Channel Antagonists: Potential Analgesics for Jejunal Pains. Pain Relief - From Analgesics to Alternative Therapies 2017. https://doi.org/10.5772/66597.

(35) Kumar, R.; Mehra, R.; Ray, S. B. L-Type Calcium Channel Blockers, Morphine and Pain: Newer Insights. Indian J Anaesth 2010, 54 (2), 127-131. https://doi.org/10.4103/00195049.63652.

(36) Prado, W. A. Involvement of Calcium in Pain and Antinociception. Brazilian Journal of Medical and Biological Research 2001, 34 (4), 449-461. https://doi.org/10.1590/S0100879X2001000400003.
(37) Del Pozo, E.; Caro, G.; Baeyens, JoséM. Analgesic Effects of Several Calcium Channel Blockers in Mice. European Journal of

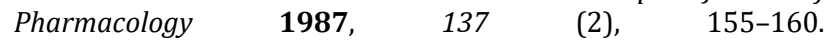
https://doi.org/10.1016/0014-2999(87)90216-0.

(38) Ray, S. B.; Mishra, P.; Verma, D.; Gupta, A.; Wadhwa, S. Nimodipine Is More Effective than Nifedipine in Attenuating Morphine Tolerance on Chronic Co-Administration in the Rat TailFlick Test. Indian J Exp Biol 2008, 46 (4), 219-228.

(39) GOLD - Protein Ligand Docking Software - The Cambridge Crystallographic Data Centre (CCDC) https://www.ccdc.cam.ac.uk/solutions/csd-discovery/Components/Gold/.

(40) I-TASSER server for protein structure and function prediction https://zhanglab.ccmb.med.umich.edu/I-TASSER/.

(41) Eldridge, M. D.; Murray, C. W.; Auton, T. R.; Paolini, G. V.; Mee, R. P. Empirical Scoring Functions: I. The Development of a Fast Empirical Scoring Function to Estimate the Binding Affinity of Ligands in Receptor Complexes. J Comput Aided Mol Des 1997, 11 (5), 425-445. https://doi.org/10.1023/a:1007996124545.

(42) Baxter, C. A.; Murray, C. W.; Clark, D. E.; Westhead, D. R.; Eldridge, M. D. Flexible Docking Using Tabu Search and an Empirical Estimate of Binding Affinity. Proteins 1998, 33 (3), 367-382.

(43) Manual for Preclinical Studies of New Pharmacological Substances. Part I, Ed. Mironov, A.N., Moscow, 2013. (in Russian).

(44) Rice, A. S. C.; Cimino-Brown, D.; Eisenach, J. C.; Kontinen, V. K.; Lacroix-Fralish, M. L.; Machin, I.; Preclinical Pain Consortium; Mogil, J. S.; Stöhr, T. Animal Models and the Prediction of Efficacy in Clinical Trials of Analgesic Drugs: A Critical Appraisal and Call for Uniform Reporting Standards. Pain 2008, 139 (2), 243-247. https://doi.org/10.1016/j.pain.2008.08.017.

(45) Woolfe, G.; Macdonald, A. D. The Evaluation of the Analgesic Action of Pethidine Hydrochloride (Demerol). J Pharmacol Exp Ther 1944, 80 (3), 300-307.

(46) Koster R; Anderson M; De Beer E.j. Acetic Acid-Induced Analgesic Screening. Federation Proceedings 1959, 18 (0), 412412.

(47) Randall, L. O.; Selitto, J. J. A Method for Measurement of Analgesic Activity on Inflamed Tissue. Arch Int Pharmacodyn Ther 1957, 111 (4), 409-419.

(48) Barrot, M. Tests and Models of Nociception and Pain in Rodents. Neuroscience 2012, 211, 39-50. https://doi.org/10.1016/j.neuroscience.2011.12.041.

(49) Jones, G.; Willett, P.; Glen, R. C.; Leach, A. R.; Taylor, R. Development and Validation of a Genetic Algorithm for Flexible

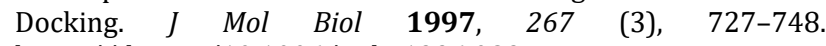
https://doi.org/10.1006/jmbi.1996.0897.

(50) Mooij, W. T. M.; Verdonk, M. L. General and Targeted Statistical Potentials for Protein-Ligand Interactions. Proteins 2005, 61 (2), 272-287. https://doi.org/10.1002/prot.20588.

(51) Martínez, J. M.; Martínez, L. Packing Optimization for Automated Generation of Complex System's Initial Configurations for Molecular Dynamics and Docking. J Comput Chem 2003, 24 (7), 819-825. https://doi.org/10.1002/jcc.10216.

(52) Martínez, L.; Andrade, R.; Birgin, E. G.; Martínez, J. M. PACKMOL: A Package for Building Initial Configurations for Molecular Dynamics Simulations. J Comput Chem 2009, 30 (13), 2157-2164. https://doi.org/10.1002/jcc.21224.

(53) Schott-Verdugo, S.; Gohlke, H. PACKMOL-Memgen: A Simple-To-Use, Generalized Workflow for Membrane-Protein-Lipid-Bilayer System Building. J Chem Inf Model 2019, 59 (6), 2522-2528. https://doi.org/10.1021/acs.jcim.9b00269.

(54) Jorgensen, W. L.; Chandrasekhar, J.; Madura, J. D.; Impey, R. W.; Klein, M. L. Comparison of Simple Potential Functions for Simulating Liquid Water. J. Chem. Phys. 1983, 79 (2), 926-935. https://doi.org/10.1063/1.445869.

(55) Neria, E.; Fischer, S.; Karplus, M. Simulation of Activation Free Energies in Molecular Systems. J. Chem. Phys. 1996, 105 (5), 1902-1921. https://doi.org/10.1063/1.472061. 